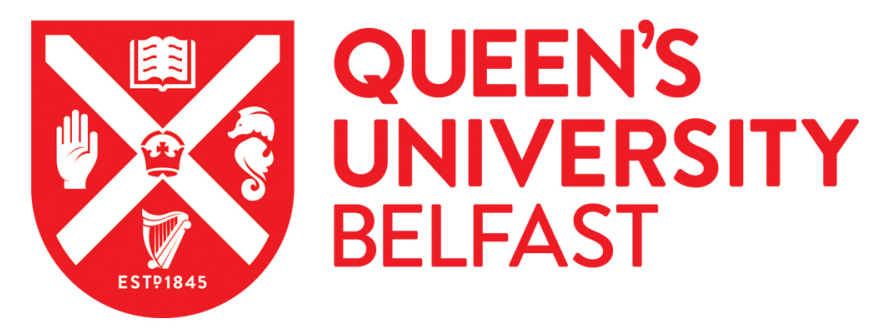

\title{
The Collateral Consequence Conundrum: Comparative Genealogy, Current Trends, and Future Scenarios
}

Corda, A. (2018). The Collateral Consequence Conundrum: Comparative Genealogy, Current Trends, and Future Scenarios. In A. Sarat (Ed.), Studies in Law, Politics, and Society (Vol. 77, pp. 69-97). Emerald Publishing. https://doi.org/10.1108/S1059-433720180000077004

Published in:

Studies in Law, Politics, and Society

Document Version:

Publisher's PDF, also known as Version of record

Queen's University Belfast - Research Portal:

Link to publication record in Queen's University Belfast Research Portal

Publisher rights

Copyright 2018 Emerald. This work is made available online in accordance with the publisher's policies. Please refer to any applicable terms of use of the publisher.

\section{General rights}

Copyright for the publications made accessible via the Queen's University Belfast Research Portal is retained by the author(s) and / or other copyright owners and it is a condition of accessing these publications that users recognise and abide by the legal requirements associated with these rights.

Take down policy

The Research Portal is Queen's institutional repository that provides access to Queen's research output. Every effort has been made to ensure that content in the Research Portal does not infringe any person's rights, or applicable UK laws. If you discover content in the Research Portal that you believe breaches copyright or violates any law, please contact openaccess@qub.ac.uk. 


\section{emeraldinsight}

\section{After Imprisonment}

The Collateral Consequence Conundrum: Comparative Genealogy, Current Trends, and Future Scenarios

Alessandro Corda,

\section{Article information:}

To cite this document: Alessandro Corda, "The Collateral Consequence Conundrum: Comparative Genealogy, Current Trends, and Future Scenarios" In After Imprisonment. Published online: 22 Oct 2018; 69-97.

Permanent link to this document:

https://doi.org/10.1108/S1059-433720180000077004

Downloaded on: 30 October 2018, At: 04:27 (PT)

References: this document contains references to 0 other documents.

To copy this document: permissions@emeraldinsight.com

Access to this document was granted through an Emerald subscription provided by emerald-srm: 198285 []

\section{For Authors}

If you would like to write for this, or any other Emerald publication, then please use our Emerald for Authors service information about how to choose which publication to write for and submission guidelines are available for all. Please visit www. emeraldinsight. com/ authors for more information.

\section{About Emerald www.emeraldinsight.com}

Emerald is a global publisher linking research and practice to the benefit of society. The company manages a portfolio of more than 290 journals and over 2, 350 books and book series volumes, as well as providing an extensive range of online products and additional customer resources and services.

Emerald is both COUNTER 4 and TRANSFER compliant. The organization is a partner of the Committee on Publication Ethics (COPE) and also works with Portico and the LOCKSS initiative for digital archive preservation.

*Related content and download information correct at time of download. 


\title{
THE COLLATERAL CONSEQUENCE CONUNDRUM: COMPARATIVE GENEALOGY, CURRENT TRENDS, AND FUTURE SCENARIOS
}

\author{
Alessandro Corda
}

\begin{abstract}
Collateral consequences (CCs) of criminal convictions such as disenfranchisement, occupational restrictions, exclusions from public housing, and loss of welfare benefits represent one of the salient yet hidden features of the contemporary American penal state. This chapter explores, from a comparative and historical perspective, the rise of the many indirect "regulatory" sanctions flowing from a conviction and discusses some of the unique challenges they pose for legal and policy reform. US jurisprudence and policies are contrasted with the more stringent approach adopted by European legal systems and the European Court of Human Rights (ECtHR) in safeguarding the often blurred line between criminal punishments and formally civil sanctions. The aim of this chapter is twofold: (1) to contribute to a better understanding of the overreliance of the US criminal justice systems on CCs as a device of social exclusion and control, and (2) to put forward constructive and viable reform proposals aimed at reinventing the role and operation of collateral restrictions flowing from criminal convictions.
\end{abstract}

Keywords: Collateral consequences; punishment; reentry; criminal records; comparative penology; sentencing

After Imprisonment: Special Issue

Studies in Law, Politics, and Society, Volume 77, 69-97

Copyright (C) 2019 by Emerald Publishing Limited

All rights of reproduction in any form reserved

ISSN: 1059-4337/doi:10.1108/S1059-433720180000077004 


\section{INTRODUCTION}

Over the past four decades, the issue of incarceration has gradually come to dominate the scholarly and policy debate on criminal justice in the United States (Garland, 2001a; Zimring, 2010; Zimring \& Hawkins, 1991). The explosion of imprisonment rates in America, particularly beginning in the 1980s, resulted chiefly from a range of increasingly punitive "tough on crime" sentencing policies (Tonry, 2016, 1996; Mauer, 2001) and the behavior of overzealous prosecutors responding to local political imperatives (Pfaff, 2017). The combination of these policies and practices led to a growth of incarceration unparalleled in any other developed Western country and unprecedented in American history. As a result, the discussion over causes of mass incarceration and possible ways to reverse it overshadowed several other distinctive characteristics that make the United States an exceptional nation in terms of harshness of its penal policies and institutions (Reitz, 2018).

In recent years, however, the focus has gradually shifted to encompass a broader range of issues in the ongoing discussion on criminal justice reform. Looking beyond imprisonment, scholars in the field of sentencing and corrections have identified two subjects in particular that nearly went undetected and have been under-researched until recently: (1) mass penal supervision in the community, including both parole and probation (Phelps, 2013; van Zyl Smit \& Corda, 2018) and (2) mass imposition of burdensome civil disabilities (either automatically or discretionarily) on criminally convicted persons. Such disabilities are commonly referred to as "collateral consequences" of criminal convictions. Examples include, among many others: disenfranchisement, occupational restrictions, exclusions from public housing, loss of welfare benefits, loss of the right to bear arms, and a prohibition on holding public offices and serving as a juror. This chapter explores the latter phenomenon.

Collateral consequences (CCs) of convictions received some attention during the 1950s through the early 1970s from scholars and reformers concerned with alleviating the hurdles faced by ex-offenders upon release from custody or discharge from probation or parole (Love, Roberts, \& Klingele, 2016, pp. 10-12; Special Project, 1970). Advocates began to challenge civil disabilities as part of a wider agenda aimed at drawing attention to the issue of re-socialization of offenders who had served out their sentences. CCs were seen as ways to exclude offenders from society and increase their likelihood of recidivism (Demleitner, 2000, p. 766). The then-dominant rehabilitative ideal was conducive to such an endeavor. Yet, before the enactment of significant legislation at the federal and state level, from the 1980s forward voices supporting the elimination of various forms of legal discrimination against persons with a criminal record succumbed to popular demand to get tough on crime and criminals.

The demise of rehabilitation (Allen, 1981) and the emergence of a "new penology" primarily focused on risk management and control of dangerous classes of persons (Feeley \& Simon, 1992, 1994; Simon, 1993) left little room for comprehensive reform aimed at removing legal disabilities imposed as a result of a criminal conviction. At the same time, in a climate characterized by policies 
and rhetoric of crime control at nearly all costs (Garland, 2001b), CCs began to grow exponentially in number and scope, though silently. They rapidly became a staple of the "shadow carceral state" comprising the less visible yet equally impactful ramifications of the US punitive institutions, mimicking traditional criminal punishment or creating pathways to it (Beckett \& Murakawa, 2012).

Over the past 15 years, however, after a long hiatus, criminal justice advocates, policy-makers, and scholars have started to focus again on the panoply of indirect sanctions that flow from a criminal conviction. At first, the input came from the growing awareness of substantial problems related to mass prisoner reentry in times of mass incarceration (Travis, 2005). With over 600,000 individuals released from state and federal prisons each year since 2000 (Carson \& Golinelli, 2013, p. 4, table 2; Carson, 2014, p. 10, table 9; Carson \& Anderson, 2016, p. 11, table 7), oftentimes after serving lengthy sentences, legal and practical barriers to a timely and effective reintegration into society have become an issue that cannot be neglected or taken lightly (Petersilia, 2003, pp. 105-137; Mears \& Cochran, 2015, pp. 125-137). It has also become apparent that even misdemeanor convictions that rarely result in jail time frequently lead to major CCs (Roberts, 2011, pp. 297-303). In this regard, it has been observed that "as a practical matter [...] collateral consequences have become more important to many criminal defendants than any penalty likely to be imposed by the court" (Love, 2015, p. 250).

This renewed attention to CCs has produced a massive body of scholarly work since the beginning of the twenty-first century. Civil penalties that attach to criminal convictions have been challenged at different levels and from different angles and perspectives. The goal of this chapter is not to systematically review the extensive literature on the topic of CCs that has been published in recent years. Rather, my aim is twofold: first, to contribute to a better understanding of present-day challenges posed by the undue overreliance of the criminal justice system on formally nonpunitive statutory schemes that accompany criminal convictions, often lacking a clear link with the underlying offense; and second, to highlight different options to deal with CCs at the legislative and judicial level, and put forward some modest suggestions for reform. In so doing, I will use the tools of legal history and comparative law to trace the origins and development of collateral sanctions arising from a criminal conviction.

This chapter proceeds in four parts. First, I sketch a comparative genealogy of CCs. "Collateral" restrictions linked to criminal convictions originated in Europe as a form of punishment and later became an early example of legal transplant from the Old World to the New World. Yet, regardless of the common roots, CCs in the United States developed in a completely different fashion over time. The tracing of lines of descent and development of CCs allows shedding light on what prevented American jurisdictions from scrutinizing and selecting disabilities arising from a conviction and eventually integrating a few of them into a coherent framework of criminal penalties, opting instead for the civil/regulatory classification. In the second part, I then discuss the multifaceted notion of "collateral consequences of conviction" and describe how they rose to become a prominent feature of today's American penal state. The third part of 
the chapter focuses on the role of the courts. I analyze how the more stringent approach of the European Court of Human Rights (ECtHR) has proved more effective than the deferential approach of the US judicial actors in safeguarding the often blurred line between criminal punishments and civil measures. Finally, I discuss pros and cons of different options to deal with CCs, namely: (1) recognizing them as forms of state regulation aimed at preventing risk to be imposed by non-criminal justice actors when deemed necessary to achieve public safety/ harm prevention goals; (2) integrating, to various degrees, "civil" CCs into the sentencing stage of the criminal process; and (3) acknowledging CCs as formal punishment.

\section{A COMPARATIVE GENEALOGY OF COLLATERAL CONSEQUENCES}

Modern-day CCs have their roots in the two ancient concepts of "civil death" and "infamy." The two concepts are distinct, yet they have been occasionally confused and conflated by scholars and court opinions. Civil death came first in classical antiquity. The perpetrator of certain heinous crimes was pronounced "civilly dead," that is dead in the view of the law. The civilly dead lost all his civil rights and capacities and could also be killed with impunity. As the Greek and Roman civilizations reached their maturity, "a more humane approach toward disabilities flowing from convictions of crime prevailed" (Damaška, 1968, p. 351). Civil death was maintained for crimes deemed exceptionally grave such as treason, while infamy operated more frequently following a conviction for "public crimes" or "crimes of moral turpitude." Infamy thus developed historically as a milder form of deprivation of rights for offenders who committed crimes not entailing a permanent removal from society.

In Athens and other Greek city-states, the punishment of infamy ( $\dot{\alpha} \tau \mu$ í $\alpha$, meaning "without honor or value" or "public disgrace") was imposed by the court and triggered the full or partial loss of citizenship rights, especially for crimes entailing an abuse of such rights. Subject to the penalty of infamy were also offenses involving failing to comply with duties toward one's family (e.g., failure to assist one's parents or mistreating them) and the community (e.g., failure to honor a debt, false testimony, and bribery of public officials; Manza \& Uggen, 2006, p. 23). In Roman law, infamy (infamia) was applied to individuals convicted for serious crimes deemed "dishonorable" or "infamous." Like its Greek counterpart, Roman infamy involved the forfeiture or abridgment of the offender's political and social rights. The infamis (the person subject to infamy) was incapable of holding any public office (honores). Infamy also entailed the loss of the capacity to be a witness in court proceedings, file a public indictment, represent another citizen, and, in addition, often deprived the convicted of the right to vote (suffragium; Pettus, 2013, pp. 26-28).

Roman law distinguished between immediata infamia (immediate or de facto infamy) and mediata infamia (indirect or de jure infamy). Immediate infamy descended upon a person after the commission of some acts that were deemed to deserve social condemnation with no need for a court judgment. For example, 
immediate infamy attached to persons who engaged in a disreputable trade and to soldiers ignominiously discharged from service. Unlike immediate infamy, indirect infamy did not spontaneously arise from a certain behavior, "but only after a court of law had passed judgment on the delinquent on the ground of some act which deserved to be visited with social disgrace" (Sohm, 1892, p. 128). In Roman criminal law, too, infamy arising from a conviction was regarded as formal punishment, more precisely as a "supplementary" criminal penalty (von Bar, 1916, p. 37).

Labels must not deceive here. The second type of infamy was "indirect" only insofar as it required a conviction, and not merely a de facto situation, to be imposed. It did represent a direct consequence of being found guilty of specified offenses. Yet infamy was not explicitly announced at sentencing by the court: civil disabilities automatically followed a conviction as "penal consequences" of it. De jure infamy represented, therefore, a tacit yet mandatory direct consequence ensuing from conviction for certain grave and dishonorable crimes.

After the fall of the Roman Empire, Germanic tribes revived civil death as "outlawry" for particularly serious crimes. The outlaw was expelled from the community and deprived of his legal existence (Itzkowitz \& Oldak, 1973, pp. 722-723). England developed its own model of imposing civil death as punishment named "attainder," the stain arising from being convicted of a heinous crime, namely treason or a felony offense. A person declared "attainted" had his civil and political rights nullified and his property forfeited (Parkes, 2003, p. 74). Furthermore, attainder caused the "corruption of blood" of the offender's descendants (Singer, 2002, p. 249). Originally, being convicted for treason or felonies at common law resulted in the imposition of capital punishment, so the penalty of attainder represented "a practical way of settling the earthly affairs of a convicted felon soon to be executed" (Saunders, 1970, p. 990; see also Blackstone, 1769, pp. 373-374). American colonies imported attainder from England. Yet, after the American Revolution, the new states modified the English version of civil death. Colonial versions of attainder were extended to offenses not punished by death - in particular those defined as egregious violations of the moral code of the community ("crimes of moral turpitude" or "infamous crimes"). American colonies also started to question the perpetual character of deprivation of certain rights following conviction (Ewald, 2002, pp. 1060-1061). In a sense, this processes resembled the emergence of infamy in Ancient Greek and Rome as a milder version of civil death.

The US Constitution in 1789 explicitly forbade legislative bills of attainder at the federal and state level (Article I, Sections 9-10). Article III, Section 3 prohibited corruption of blood or forfeiture for treason, "except during the life of the person attainted." Despite the importance the framers of the Constitution gave to the issue, in 1799 New York State enacted the first "civil death" statute in the United States targeting persons sentenced to imprisonment for life, who were deprived of all civil rights. At least a third of American states followed in the footsteps of NY legislation (McLennan, 2011, p. 195). In the mid-twentieth century, most civil death statutes were repealed or voided, wholly or in part, by court decisions (Chin, 2012, pp. 1797-1798). However, while the medieval 
fiction of civil death gradually faded away, over time various forms of disqualification and disenfranchisement laws emerged. A wide variety of legal rights and benefits were denied to those convicted of a crime, sometimes on the basis of the felony/misdemeanor distinction, sometimes irrespective of the gravity of the offense, sometimes on the basis of the infamous/non-infamous distinction, and sometimes in connection with specific crimes. Civil disabilities disappeared from penal statutes to make a comeback "in disguise" outside the realm of the criminal law as collateral sanctions triggered by a criminal conviction.

In Europe, disqualifications and other civil disabilities stemming from criminal convictions followed a different path. They have never been removed from the formal domain of the criminal process and have gradually become narrower and narrower in their scope and reach since legislatures repealed civil death statutes in the nineteenth century.

Unlike the distinction between direct and CCs of conviction in American law, today the vast majority of European Penal Codes operate a distinction between main (or principal) and ancillary (or additional) criminal penalties. Ancillary criminal penalties (e.g., Nebenstrafen in Germany, ${ }^{1}$ peines complémentaires in France, pene accessorie in Italy, penas acesorias in Spain, and ancillary orders in England and Wales) are imposed as a supplement to the principal punishment (typically imprisonment and/or fine). Less often, a combination of ancillary penalties is imposed as the only punishment. They represent an integral part of the formal sentence (Demleitner, 2000, pp. 755-756). Generally, it is left to the judge's discretion to determine whether to impose one or more ancillary penalties available for a certain crime as part of the sentence. In a few countries, ancillary penalties, when specified for certain crimes, follow by operation of law as penal consequences of conviction. Ancillary criminal penalties in Europe are "punitive in intent" and must therefore "be taken into account in calculating the overall proportionality of the sentence to the offense(s) of which the offender is convicted" (Ashworth, 2015, p. 380).

This category of penalties includes various temporary or permanent disqualifications closely tied to the nature of the underlying offense. Ancillary criminal penalties typically include the deprivation of enumerated civil rights, the ban from holding public offices, disqualifications from practicing certain professions, and the ban on driving and competitive bidding (see, e.g., Sections 44 and 45 of the German Penal Code; Article 131-10 of the French Penal Code, and Article 19 of the Italian Penal Code). Disenfranchisement can also be imposed as an ancillary penalty in a significant number of European jurisdictions (Tripkovic, 2016). Furthermore, in a few countries, the publication of the record of conviction in newspapers and/or specific websites is also part of the list for specified offenses.

While in the US many CCs are universally applied to all persons convicted of felony-level offenses (Uggen \& Stewart, 2015, p. 1872), ancillary criminal penalties in Europe can be imposed only in connection with enumerated offenses by reason of their inherent gravity or specific characteristics of the proscribed conduct. Thus, not even felony convictions unavoidably entail the loss of certain rights or other adverse consequences besides imprisonment and/or a fine. ${ }^{2}$ The 
main function of ancillary criminal penalties is rather to better fine-tune the punitive response in terms of retributive and utilitarian purposes.

The emergence of the distinction between main and ancillary penalties dates back to the nineteenth-century process of penal codification when European legal systems experienced a vast process of penal reform primarily aimed at making the institution of punishment more rational and proportionate to the adjudicated offense. Another goal of the newly created category of criminal penalties was to delimit clearly the boundaries of punishment. Ancillary criminal penalties are provided for in penal statutes pursuant to the principle of legality of criminal punishments expressed in the maxim nulla poena sine praevia lege poenali - there exists no punishment without a preexisting penal law (Corda, 2016, pp. 46-49).

It must be noted, however, that the framework making criminal punishment a genus divided into two species - main and ancillary criminal penalties - took some time to develop in full. For example, the highly influential Napoleonic Penal Code enacted in France in 1810 distinguished three kinds of offenses, corresponding to as many classes of penalties. Felonies were punishable with various penalties: death, hard labor for life, hard labor for a time, deportation, imprisonment, the pillory, banishment, and civic degradation. All these penalties were deemed "infamous" and involved for the convict automatic infamous effects, in particular, a general forfeiture of civil and political rights. While not entirely removed from the penal sphere, these automatic infamous effects carried an inherent ambiguity as to their true nature. They did not have to be explicitly imposed in court as part of the formal sentence. Furthermore, the letter of the law seemed to link them more closely to the infamous nature of the penalty announced by the judge rather than to the characteristics of the underlying offense. From a conceptual standpoint, they could be therefore easily mistaken for nothing more than an "afflictive corollary" of a judgment of guilt and subsequent punishment.

This brings us back to the Roman concept of mediata infamia. The fact that infamy was not pronounced at sentencing generated some ambiguity regarding its nature and classification as punishment. In Europe, the growing awareness regarding the burdensome ramifications stemming from being adjudicated and sentenced gradually prompted criminal law theorists to suggest a more rational and systematized taxonomy of penal consequences of criminal convictions (Corda, 2016, p. 52). Civil disabilities came to be regarded as formal penalties and not merely as "natural consequences" arising, more or less ambiguously, from the conviction for an infamous crime or the imposition of an infamous penalty. Such effort led to the adoption of the formal distinction between main and ancillary criminal penalties.

German jurist Friedrich Carl von Savigny highlighted this ostensible ambiguity in his paramount study of Roman law. Writing toward the end of the nineteenth century, he observes that, "In our own time we regard [infamy], in the first place, as a means of punishment, either occurring alone or in aggravation of another punishment." The continental understanding of infamy, he continues, can be directly traced back to the Roman mediata infamia resulting from a 
criminal conviction. Yet the Romans regarded infamy as the "natural consequence" of a conviction for specified offenses, so it was "never expressed in the sentence itself." Von Savigny (1884, p. 145) concluded noting that it is precisely the explicit and unambiguous imposition of civil disabilities at sentencing that has "materially strengthened the prevailing impression of infamy conceived as a punishment" in European criminal law.

In contrast, US scholars and lawmakers went down the opposite route and interpreted the silence at sentencing regarding the infamous consequences of a conviction as an eloquent sign: disabilities arising from a criminal conviction that are not imposed by a court as part of the formal sentence are not punishment. This led US scholars to assert with confidence that American law, "like the Roman law [...] draws and preserves a clear distinction between punishment for a crime and political and civil disabilities consequent on conviction of crime" (Schofield, 1911, p. 330). The Pandora's Box of formally nonpunitive CCs of conviction was hence opened.

\section{COLLATERAL CONSEQUENCES IN THE AMERICAN PENAL STATE}

Extensive and sticky CCs of conviction represent one of the salient facets of contemporary America's penal system (Garland, 2017, p. 4). Although not formally labeled as criminal punishment, these restrictions and disqualifications visited upon former offenders emphatically perpetuate penal control, especially for the poorest and most disadvantaged groups. They are instruments of social exclusion that create a permanent degradation in the social status of convicted persons. In today's society, CCs can be therefore characterized as "practices of social shunning" that have been largely "formalized into law" (Kurlychek, Brame, \& Bushway, 2007, p. 67).

As previously mentioned, a vast number of CCs, especially those "activated" by a felony conviction, are applied indiscriminately, with a tenuous relationship between the restriction imposed and the specific characteristics of the offense committed. Most CCs identify their triggering offenses in terms of general categories (e.g., "any felony," "crimes of violence," "crimes involving moral turpitude," etc.; Love et al., 2016). Collateral restrictions operate both during the execution of the sentence and once an offender is released from prison or discharged from community supervision. Particularly in the latter case, CCs represent not only legal barriers to reentry but also constitute moral and social hurdles for ex-offenders in the process of rejoining the community as lawabiding and productive citizens (McNeill, 2016, pp. 75-76; see also Maruna, 2001). In this regard, the stigma of a criminal record and the CCs it triggers often represent a self-fulfilling prophecy in terms of likelihood of reoffending: widespread access to criminal records information, restrictions on employment, and loss of public welfare benefits in particular are associated with higher recidivism rates (Sohoni, 2013; Whittle, 2018).

In what follows, I discuss the many-sided notion of "collateral consequences" and highlight the major factors that paved the way for the exponential growth 
of "collateral" restrictions stemming from criminal convictions in the United States, especially from the early 1980s onward.

\section{Definitional Issues}

The term "collateral consequences" refers to a complex phenomenon. Collateral consequences of convictions have been called many names: "forgotten punishment" (Cohen \& Rivkin, 1971), "invisible punishment" (Travis, 2002), and "hidden penalties" (Kaiser, 2016a) among others. Definitional nuances are symptomatic of the difficulties in outlining the concept in a coherent fashion. This is for collateral ramifications of a criminal conviction arise and manifest themselves in various ways. The core feature different types of CCs have in common is that they are distinct from the direct consequences of being found guilty in a criminal case, such as imprisonment, fines, and probation. CCs "are not part of the sentence calculus, even though they derive from a criminal conviction" (Demleitner, 2005, p. 356).

Examples of CCs include loss of civil and parental rights, occupational restrictions such as losing professional licenses, deportation, denial of public benefits, and registration requirements (specifically targeting sex offenders; Pinard, 2010, pp. 489-494). Furthermore, in today's digital age, criminal history information extends its reach well beyond the internal functioning of the criminal justice system. Criminal records are now at everyone's fingertips online through court record databases, state criminal history repositories, and private purveyors. As a result, individuals with a criminal history are more visible than ever before: the status of being a convicted person has become a central facet of ex-offenders' public identity, one that pervasively affects crucial aspects of everyday life, especially during the reentry phase (Corda, 2016; Jacobs, 2015; Lageson, 2017).

Within the category of collateral, or indirect, consequences of criminal convictions, a distinction is usually made between formal (or de jure) and informal (or de facto) CCs, depending on whether or not they arise from an explicit statutory basis. Civil disabilities enacted by federal, state, and local lawmakers, and sometimes also by administrative bodies qualify as formal CCs regardless of whether they apply by operation of law or otherwise. In contrast, all the negative ramifications "arising independently of specific legal authority, and concern [ing] the gamut of negative social, economic, medical, and psychological consequences of conviction" qualify as informal CCs (Logan, 2013, p. 1104; see also Love et al., 2016, p. 3).

For a long time, advocates and scholars have primarily focused their attention on formal CCs provided for by the law while paying relatively little attention to de facto collateral ramifications of criminal convictions. Yet it can be argued that the line dividing formal from informal CCs is more blurred than one might think. Current legal doctrines have the effect of "delegating" to private actors the power to impose informal collateral sanctions such as housing and employment discrimination, which certainly constitute something more than mere social shunning. As it has been noted, "so-called 'private' institutional 
arrangements $d o$ implicate the legal system: employers may deny prospective employees jobs because of their criminal histories, but not their religions, because we have collectively decided by law to allow the former and not the latter" (Kleinfeld, 2016, p. 969).

Private actors, such as employers and landlords, operate therefore as an arm of the criminal justice system: they effectively act as decision-makers with respect to the imposition of burdensome consequences of having a criminal record, though without proper checks (Levin, 2018). This might be regarded, to some extent, as a new frontier of outsourcing part of the state monopoly to punish crime (Husak, 2016). While blanket bans on applicants with a criminal history are generally prohibited, landlords and employers nearly systematically run background checks on applicants to screen themselves from liability. Their behavior can be characterized as a "defensive" use of what amounts to sanctioning powers.

The case of employment discrimination, in particular, is highly illustrative. Positions in certain fields, such as childcare, financial institutions, and healthcare, mandatorily require a criminal background check under federal law. Beyond such cases, courts have established a general rule that employers do not have a per se duty to investigate criminal backgrounds of prospective employees. Employers have, instead, a general duty to make a reasonable investigation of an applicant's fitness before hiring (Jacobs, 2015, pp. 277-279; Levin, 2018). However, employers systematically conduct background checks on job applicants $^{3}$ primarily as a protection against potential liability under the doctrine of negligent hiring. (The same is done periodically in regard to current employees as a shield against liability under the doctrine of negligent retention). As criminal history information has become so readily available, background checks have become standard practice: employers feel safer and believe they have performed their due diligence to prevent any possible negative consequence.

Interestingly, the current situation arises not because of explicit policies that either require or allow private actors to impose collateral burdens on applicants with a criminal record. Rather, the imposition of such burdens is boosted by the unforeseen combination of established legal doctrines and the new widespread availability of criminal records in a digitized form (Blumstein \& Nakamura, 2009, pp. 228-330).

For the reasons discussed, it has perhaps more sense to adopt a distinction between automatic and discretionary CCs of convictions, irrespective of any formal statutory basis. From this perspective, a distinction can be made between (1) collateral sanctions that apply to offenders automatically upon conviction, and (2) CCs stemming from discretionary government action or decisions of professional or licensing bodies, or private actors such as landlords or employers (Demleitner, 2016, p. 153).

This automatic/discretionary distinction too, however, presents a gray area. Consider, in particular, those cases where, even though a separate proceeding for imposing a civil or regulatory sanction is formally required, the presence of a criminal conviction is almost invariably crucial in determining the outcome of such proceeding. Think, for instance, of the non-criminal proceeding required 
for the civil commitment of sex offenders: in many jurisdictions, proof of dangerousness justifying the imposition of such an afflictive measure is directly inferred from the prior conviction for a sex crime. Another example is that of formally nonautomatic disbarment proceedings through which a lawyer can be removed from the practice of law: although such proceedings tend to be idiosyncratic, the "good moral character" requirement for bar membership is often deemed compromised by a criminal conviction, especially for a felony.

\section{The New Rise of Collateral Consequences}

The National Inventory of the Collateral Consequences of Conviction (NICCC) assembled by the American Bar Association with the help of a federal grant and launched in 2012 lists over 42,000 CCs of criminal convictions stemming from over 35,000 laws and regulations at the local, state, and federal level. Around $62 \%$ of such restrictions are employment-related. This effort supports the claim that CCs have grown so much over time in both number and sparseness to make their operation largely unpredictable (Kaiser, 2016a). During the twentieth century, the demise of civil death and infamy seemed to predict the soon-to-be disappearance of collateral restrictions and civil disabilities from US law. Three different factors that emerged at different moments during the past century, however, paved the way for, and ultimately led to, new generations of impactful collateral ramifications of criminal convictions, collectively referred to by Jack Chin (2012) as the "new civil death."

Consider first the loss of welfare benefits as a result of a criminal conviction. The American Welfare State was established by Franklin D. Roosevelt's "New Deal" in the 1930s as a response to the Great Depression and later revised and extended by Lyndon B. Johnson's "Great Society" in the 1960s and Bill Clinton's "Welfare to work" in the 1990s (Garland, 2016). Before these social welfare programs were created, until at least the mid-twentieth century in America there were considerably fewer public benefits to lose because of a criminal conviction compared to nowadays (Chin, 2012, p. 1802).

A similar point can be made about occupational licensing restrictions arising from a conviction. The widespread adoption of state occupational licensing laws represented a key feature of the rise of the regulatory state in the United States (Glaeser \& Shleifer, 2003). Such process began at the end of the nineteenth century, and by the 1950s, over 1,200 licensing laws had been passed, "averaging 25 per state, and covering over 75 different occupations." They were mostly the result of an increasing specialization of knowledge and also part of a strategy aimed at tackling information asymmetries and helping the market function more efficiently (Law \& Kim, 2011, p. 123). Before the exponential growth of occupational licensing laws, occupational restrictions flowing from a criminal conviction were way less numerous and impactful on the lives of ex-offenders.

The last factor to be considered is the shift toward more punitive criminal justice laws, policies, and practices, especially beginning in the 1980s. Punitive policies rapidly achieved an impressive popular consensus, and the mid-1990s marked the peak of the tough on crime period. Overall, those years represented 
"an era of punitive hostility unparalleled in modern US history" (Zimring, 2010, p. 1245). What Jonathan Simon (2007) so eloquently termed "governing through crime" became a central and bipartisan electorally lucrative feature of the political debate in America. In this context, crime control soon became a mode of governance and regulation. In contrast to the pre-1980s period, CCs of convictions started to grow rapidly in number and scope (Olivares, Burton, \& Cullen, 1996). Civil disabilities and restrictions imposed on ex-offenders came to represent a "hidden" yet highly effective device of exclusion for persons deemed dangerous and/or unworthy for their criminal past (Ewald, 2011).

The crackdown on welfare benefits for persons with a criminal history illustrates the point. In 1996, President Bill Clinton's welfare reform - the Personal Responsibility and Work Opportunity Reconciliation Act (PRWORA) - introduced a permanent eligibility ban on federal welfare benefits, including food stamps, for anyone convicted in state or federal courts of a felony drug offense, including marijuana possession. ${ }^{4}$ The Clinton administration also supported laws denying federal financial aid to students with drug convictions. Furthermore, other newly enacted measures made it easier to deny public housing to people with a criminal record. A "one strike and you're out" rule was passed, which meant that the commission of one offense became a legitimate basis to render a person ineligible to be admitted to or remain in public housing. Anyone convicted of producing methamphetamine in public housing or of a sex offense requiring lifetime registration is now automatically excluded from public and federally assisted housing. Moreover, public housing authorities have been given broad discretion to deny admission to individuals convicted for other offenses, especially drug-related and violent crimes. Last but not least, families can be evicted from public housing if one family member living in the premises or a guest has a criminal history for even minor drug-related criminal activity (Alexander, 2010, pp. 56-57; Silva, 2015).

Sex offender registration and notification laws are other telling examples of CCs of convictions that flourished during the tough on crime era. The first sex offender registries in the United States were enacted in the late 1940s as a way "to inform the police of the whereabouts of habitual sex offenders." The idea soon lost favor to so-called sexual psychopath laws. By the 1970s, however, such laws had likewise lost approval, "either being repealed or widely ignored as ineffective and unjust policies" (Hoppe, 2016, p. 577; see also Rice Leave, 2009). Everything changed in the 1990s, following high profile cases of abduction and sexual torture of children in the above-described climate of raising punitiveness.

The first state sex offender law was passed in Washington State in 1990 providing only for a registration requirement for people convicted for certain sexual offenses. In 1994, Congress passed the Jacob Wetterling Crimes Against Children and Sexually Violent Offender Registration Act requiring states to implement sex offender registries. The 1996 Megan's Law required each state to provide notification and information to communities about convicted sex offenders living in the area. This federal law applies to all sex offenders irrespective of whether their victims were children or adults. The subsequent Sex Offender Registration and Notification Act of 2006 (SORNA) mandated the creation of a 
nationwide online registration and notification system and provided a set of minimum standards across the United States (Jones \& Newburn, 2013, pp. 444-446; Logan, 2009, pp. 49 ff.). Several other "regulatory" restrictions targeting sex offenders have been passed in at least 30 states; for example, registered sex offenders often cannot live near day-care centers, schools, or parks. Sex offenders have become the suspect class par excellence, pariahs oftentimes left with no alternatives than living as exiled at home (Jackson \& Feige, 2013; Tewksbury, 2007).

The current size of felon disenfranchisement in America is, likewise, a poisonous fruit of the tough on crime era. Beginning with the Civil Rights era, restrictions on the voting rights of convicted persons have gradually diminished significantly (Uggen, Behrens, \& Manza, 2005, p. 309). However, the unprecedented rise in felony convictions that has occurred since the mid-1970s has led to an exponential growth of people subject to disenfranchisement. ${ }^{5} \mathrm{~A}$ recent study of the Sentencing Project reported that in 2016 an estimated 6.1 million people were disenfranchised due to a felony conviction, up from 1.2 million in 1976 (Uggen, Larson, \& Shannon, 2016).

\section{"DON'T YOU RECOGNIZE PUNISHMENT WHEN YOU SEE IT?": COLLATERAL CONSEQUENCES AND THE ROLE OF THE COURTS}

\section{US Courts: A Jurisprudence of Deference}

Seemingly with little remorse, the US courts appear to have bought into the idea that CCs constitute mere "side effects" of conviction, totally unrelated to the criminal justice process and criminal law principles. The exponential growth of CCs in the US over the past four decades has been due, to a great extent, to the excessive deference shown by courts to federal and state legislatures. Simply classifying such onerous and afflictive restrictions as "regulatory" measures aimed at promoting public safety and various other goals has been deemed sufficient to make the state prevail in courts in what has been dubbed the "civil-criminal labeling game" (Dershowitz, 1973, p. 1295). Consequently, the inherent punitive purpose of many civil regulations triggered by a conviction is fictitiously obfuscated by their formal classification. The jurisprudence of the US Supreme Court, in particular, has "continued the fiction" that CCs serve no punitive function (Demleitner, 2014, p. 962), thereby making constitutional constraints on the state's power to punish inapplicable - in particular the Ex Post Facto Clause, the Eighth Amendment, and the Double Jeopardy Clause.

Constitutional challenges against CCs of conviction such as felon disenfranchisement, civil commitment, and sex offender registration have been rejected based on the argument that they constitute mere civil regulatory measures rather than genuine punitive sanctions. For example, in Trop vs Dulles (1958), the Court held that felon disenfranchisement does not constitute punishment, but rather a nonpenal exercise of the state power to regulate the franchise, and therefore is not cognizable under the Eighth Amendment. In Kansas vs 
Hendricks (1997), the Court asserted that the indefinite post-sentence commitment of individuals convicted of a sex offense and deemed dangerous by the state due to a mental illness does not violate Double Jeopardy guarantees since it merely involves "civil" rather than "criminal" commitment. In Smith vs Doe (2003), the Court held that sex offender registration laws are nonpunitive and may be enforced ex post facto. In their analysis, the US courts "generally give great deference to the legislature's stated intent and rely heavily on the statutory language and legislative history of the statute" (Robinson, 2005, p. 351; see also Lucken, 2013). Whether a statutory scheme is civil or criminal is therefore usually resolved primarily as a question of statutory intent.

Even when the Supreme Court has attempted to establish a test for determining whether a sanction is a criminal punishment or civil regulation, the outcome has not been particularly helpful or stringent. According to the test developed in the 1963 case Kennedy vs Mendoza-Martinez, if the legislative intent was to establish a civil regulatory scheme, then courts must closely examine seven nonexhaustive, unweighted factors to determine whether the burden imposed by the statute is punitive in effect. ${ }^{6}$ Furthermore, only "clearest proof" will suffice to override legislative intent and "transform" what has been labeled a civil measure into a criminal punishment for the application of constitutional guarantees. Not surprisingly, thus far no civil regulation has ever been found to be punitive in nature under such test, inherently characterized by fuzziness and an extremely high burden of proof for those challenging a statute as imposing punishment (Kaiser, 2016b, p. 355; Logan, 1998, p. 1282).

A radical shift in the US courts' jurisprudence regarding the civil/criminal divide does not seem in sight. However, a few recent judicial decisions might signal a slowly growing awareness of the inherent punitive nature of certain legislative measures deemed to be regulatory and nonpunitive schemes. For example, in a remarkable decision issued in 2016, Does vs Snyder, the US Court of Appeals for the Sixth Circuit held that amendments to Michigan's Sex Offender Registration Act (SORA) are unconstitutional because they impose retroactive punishment on sex offenders in violation of the Constitution's prohibition on ex post facto laws (Does \#1-5 vs Snyder, 2016). The court looked at five of the seven nondispositive Mendoza-Martinez factors and concluded that all five supported a finding that various provisions of SORA were indeed punitive. In particular, the court observes, while the vast array of restrictions retroactively imposed on convicted sex offenders "is not identical to any traditional punishments, it meets the general definition of punishment, has much in common with banishment and public shaming, and has a number of similarities to parole/probation" (Snyder, p. 703). ${ }^{7}$

State courts too are increasingly applying a stricter scrutiny analysis to certain CCs, especially on ex post facto grounds. For example, a noteworthy 2013 decision of the Maryland Court of Appeals, Doe vs Department of Public Safety and Correctional Services, struck down a new registration requirement for convicted sex offenders on the basis that it violated a clause in the Maryland Declaration of Rights prohibiting retroactive laws. The majority opinion observed, "Registration was imposed, over twenty years later in 2009, under the 
sex offender registration statute as a direct consequence of Petitioner's commission and conviction for his sex crime. The application of the statute has essentially the same effect upon Petitioner's life as placing him on probation and imposing the punishment of shaming for life, and is, thus, tantamount to imposing an additional sanction for Petitioner's crime" (Doe, p. 40).

\section{European Courts: An Anti-subversion Jurisprudence}

The American way of dealing with CCs of convictions is in sharp contrast with the European approach. The differing attitudes toward collateral sanctions in the United States and Europe can be explained by differing basic ideologies of punishment and criminal justice, and a different approach of courts toward interpreting constitutions and enforcing basic principles of criminal punishment in the context of collateral restrictions.

European criminal justice policies and punishment schemes, including CCs, are enacted and justified with hyperspecific rationales and an intense focus on proportionality. ${ }^{8}$ Penal systems in Europe distinguish between main and ancillary criminal sanctions and "courts are required to consider the impact of all combined sanctions on the defendant and society in light of the purposes of punishment" (Demleitner, 2009, p. 86). Collateral restrictions in the United States, instead, are not taken into account in determining the overall proportionality of the sentence to the seriousness of the offense since they are not considered as punishment. ${ }^{9}$ Furthermore, Europe never moved completely away from a rehabilitative model of punishment. Even though increasingly punitive policies have been enacted in recent decades, the ultimate goal of European penal systems widely remains the reintegration of ex-offenders (Whitman, 2003, p. 73). ${ }^{10}$ In contrast, the approach toward collateral restrictions in the United States tends to mirror prevailing criminal justice attitudes oriented primarily toward harsh and prolonged measures of penal control.

Yet, all that glitters is not gold. In Europe, too, especially over the past three decades, the enactment of a growing number of civil and "regulatory" measures has attempted to reshape and subvert the boundaries of criminal punishment. However, this attempt of subversion has not gone unnoticed. Domestic courts and, in particular, the ECtHR have stood up against the erosion of basic principles and protections and have insisted on substance over form in determining what constitutes punishment (Ashworth, 2008, pp. 421-422; Zedner, 2016). The approach of European courts is therefore in stark contrast to the marked judicial deference exhibited by US judges regarding legislative labels of "criminal" or "civil." While the ECtHR's jurisprudence has sought to develop standards that apply to sanctioning policies in the broad sense, the US Supreme Court has established a "minimal constitutional floor," which has allowed states a broad and often unfettered discretion in enacting a wide patchwork of burdensome regulatory sanctions, which frequently pursue punitive goals although located outside the formal domain of criminal punishment (Demleitner, 2009, p. 103). ${ }^{11}$

As it has been noted, "[j] udicial deference is a hazard because if courts uncritically accept the legislative designation of a measure as not punishment the lesser 
procedural protections of civil or administrative procedure apply." Unlike their American counterparts, European courts "have challenged formal designations, looked behind legislative labels and insisted upon the right to apply independent criteria to determine whether or not a measure is punishment, irrespective of its official status" (Zedner, 2016, p. 11).

In so doing, courts in the Old Continent, first and foremost the ECtHR, "have challenged the notion that the defining punishment is a matter of legislative feat and instead insisted that terms like criminal charge and penalty are properly matters for the courts" (Zedner, 2016, pp. 11-12).

Undeniably, the ECtHR's case law, in particular, represents nothing less than an "anti-subversion device [...] to prevent governments from manipulating the criminal/civil boundary" (Ashworth \& Horder, 2013, p. 3).

Over time, the jurisprudence of the ECtHR has developed an autonomous notion of "criminal matter" (see Engel and Others vs the Netherlands, 1976, and its progeny). Within this jurisprudence, the Court has developed autonomous concepts of "criminal charge" as per Article 6 (procedural safeguards in criminal proceedings), and "criminal offense" and "criminal penalty" as per Article 7 of the European Convention on Human Rights (no crime, no punishment without law - nullum crimen, nulla poena sine lege).

Article 7 represents the European equivalent of the US Ex Post Facto Clause. With specific regard to penalties, Article 7(1) prohibits the imposition of more severe penalties than those that were applicable at the time the offense was committed. The leading case is Welch vs the United Kingdom (1995) where the Court stated that "To render the protection offered by Article 7 effective, the Court must remain free to go behind appearances and assess for itself whether a particular measure amounts in substance to a "penalty"” (§27).

In Welch, the Court set out the criteria to determine autonomously whether a specific measure is substantively a "penalty" within the meaning of Article 7(1), regardless of the qualification given under national law (Schabas, 2015, pp. 345-346).

The starting point for any assessment of the existence of a "criminal penalty" is to ascertain whether the measure in question is imposed following conviction for a "criminal offense." Other factors that may be also taken into account in this respect are as follows: (1) "the nature and purpose of the measure in question" (particularly its punitive aim), (2) "its characterization under national law," (3) "the procedures involved in the making and implementation of the measure," and (4) "its severity" (Welch vs the United Kingdom, § 28). However, "the severity of the measure is not in itself decisive, since many nonpenal measures of a preventive nature may have a substantial impact on the person concerned" (Welch vs the United Kingdom, § 32).

Thus, unlike what happens in the US system, formally civil or regulatory sanctions may be challenged on ex post facto grounds. It is meaningful that two very similar cases, both involving ex post facto civil commitment schemes Kansas vs Hendricks (1997) and M. vs Germany (2009) - have been decided in opposite ways on the different sides of the Atlantic as far as the definition of what is "punitive" is concerned (Slobogin, 2013). The ECtHR held that the 
retroactive application of the modified German preventive detention scheme ought to be qualified as a "penalty" for the purposes of Article 7(1) of the Convention. At the same time, it must be noted that the record of the ECtHR's jurisprudence on the retroactive imposition of "penalties" is not totally uncontroversial. For example, it has been held that the retroactive obligation for convicted sex offenders to register in a national Sex Offender Database pursues a purely preventive and dissuasive aim and therefore cannot be regarded as punitive in nature (Gardel vs France, 2009).

But what about formally nonpunitive sanctions not involving any ex post facto issue?

It must first be noted that, within the framework of the European Convention on Human Rights, the classification of a certain measure as a "penalty" for the purposes of Article 7 is also relevant in determining the applicability of the ne bis in idem rule (equivalent to the US Double Jeopardy Clause) provided for in Article 4 of Protocol No. 7 to the Convention. In the case of automatic $\mathrm{CCs}$ of a criminal conviction, no double jeopardy violation could be found for they flow from the same proceeding. If certain conditions are met, however, this type of collateral ramifications may be challenged on grounds of vagueness - that is lack of clarity making the overall punitive response following a conviction unpredictable. In its case law, the ECtHR has repeatedly maintained that the principle of legality of punishment entails that the qualitative requirements of accessibility and foreseeability must be satisfied with regard to the penalties the charged offense carries. If need be, the defendant must be assisted by the court when the full range of punitive consequences potentially stemming from a conviction is unclear (see, e.g., Kafkaris vs Cyprus, 2008, $\S 140$ ). This would be the case, as it frequently happens in the US context, when collateral sanctions are scattered throughout numerous laws, inconspicuous, and of variable application (Kaiser, 2016a; Wolff, 2011, p. 192). More generally, the jurisprudence of the ECtHR adopts what can be called a "holistic" approach to the subject of penalties. Sentencing judges are therefore encouraged to be aware of the full panoply of punitive restrictions automatically flowing from a conviction, so as to take them into account in calculating an appropriate sentence.

Things are different in case of restrictions formally labeled as civil yet punitive in nature imposed as a result of an additional proceeding arising from the same offense. This is in light of the ne bis in idem principle. In the European context, many severe, nonautomatic CCs "American style" might be held in violation of the right not to be punished twice under the criminal law for the same offense. In contrast, as previously noted, CCs are deemed civil/regulatory measures by the US courts and, for this reason, cannot be challenged on double jeopardy grounds (Pinard, 2006, pp. 640-641).

However, in a recent judgment, the Grand Chamber of the ECtHR seems to have weakened the protection offered by the ne bis in idem principle. In the case of $A$ and $B$ vs Norway (2016), the Court ruled that Art. 4 of Protocol No. 7 is not violated by dual proceedings arising from the same conduct, provided that certain conditions are fulfilled. The case concerned two taxpayers who claimed that they had been prosecuted and punished twice - in administrative and 
criminal proceedings - for the same offense. The Court observed that, "whilst different sanctions were imposed by two different authorities in different proceedings, there was nevertheless a sufficiently close connection between them, both in substance and in time, to consider them as forming part of an integral scheme of sanctions" $(\$ 147) .^{12}$

\section{DISCUSSION OF POLICY PROPOSALS}

In this final part, I discuss three policy framework proposals that have been put forward by scholars, professional associations, and independent organizations to deal more appropriately and more justly with CCs of criminal convictions.

\section{Collateral Consequences as Preventive Regulation}

A body of scholarship argues that CCs of conviction should not be conceived and treated as punishment but rather as measures that are part of the broad state regulatory power aimed at preventing the risk of future harm. Some propose to accept CCs as nonpunitive state regulation and then criticize them for being an excessive and unjust interference of the government with citizens' liberty (Cullen, Lero Jonson, \& Mears, 2017, p. 76).

Others adopt a "regulatory approach" to CCs starting from a normative definition of punishment strongly rooted in a notion of desert proportionality - a theory that does not easily tolerate utilitarian concerns and objectives: sentences should be proportionate in their severity to the gravity of the offense committed (von Hirsch \& Wasik, p. 1997; Mayson, 2015). While these authors acknowledge that it is difficult to develop a unitary account of CCs for they are often distributed along a punishment-prevention spectrum, it has been argued that collateral restrictions generally claim primary authorization "from a judgment of future risk" while punishment, on the contrary, inherently "claims normative authorization from a judgment of past culpability" (Mayson, 2015, p. 305). Along these same lines, it has been also contended that purely incapacitative measures cannot be considered as punishment at all: "locking people in prison with the sole aim of incapacitating them [...] does not constitute punishing them," and this is for only measures that are intentionally condemnatory for a past conduct and burdensome qualify as such (Hoskins, 2016, pp. 260-261).

Within this framework, a heightened scrutiny is proposed that would require the state to demonstrate that CCs triggered by a conviction represent a justifiable, cost-effective, and reasonable means to achieve their public safety/harm prevention goal in the individual case. According to its proponents, only a few collateral restrictions would eventually pass the test and survive (von Hirsch \& Wasik, 1997, p. 624; Mayson, 2015, pp. 359-360).

I certainly appreciate and concur in the proposal to reject a blanket judgment of future risk arising from the status of being a convicted offender. However, this proposal is not immune from criticism. First, it seems to forget there are actually five generally accepted goals of sentencing (retribution, deterrence, incapacitation, restoration, and rehabilitation) and that in the US none of them has primacy. As 
the Supreme Court has noted in Ewing vs California (2003), the Constitution "does not mandate adoption of any one penological theory. A sentence can have a variety of justifications, such as incapacitation, deterrence, retribution, or rehabilitation." It is therefore impossible, both from a theoretical and from a practical standpoint, to rule out a measure as not constituting punishment only because, either primarily or exclusively, it pursues a preventive goal. As it has been noted, "borders between penal and non-penal measures cannot be set by reference to purpose alone; so the claim that a measure is primarily preventive does not necessarily take it outside the realm of punishment" (Zedner, 2016, p. 7).

In virtually any jurisdiction at the federal and state level sentencing policies and practices consider, at least to some degree, utilitarian concerns including risk-prevention. In a non-negligible number of cases, they can even trump retributive proportionality considerations (Hamilton, 2015, pp. 271-277). The proposed framework thus appears as an "idealized" model that does not fully consider the reality of sentencing law, policy, and practices.

Second, by not integrating punishment and CCs in any way, the suggested model does not provide for any "overall proportionality cap," neither in terms of retributive-proportionality nor in terms of utilitarian "ends-benefits" proportionality concerned with the suitability of means to ends (Frase, 2013, pp. 32-33). Absent any such cap, there is potentially no limit to the number of burdensome consequences flowing from a criminal conviction, first as criminal punishment and then as regulatory measures. In particular, the offender risks preventative considerations to be appraised first at sentencing and then also at a later time in connection with the application of certain CCs. Furthermore, as long as a given collateral restriction meets the above-listed criteria (justifiability, cost-effectiveness, and reasonableness), it should be applied regardless of the broader punitive context in which it is inscribed.

Third, an individualized risk assessment in a risk-averse society like the one we live in does not necessarily entail that a significant number of CCs is set aside. Decision-makers might decide to err on the side of safety (Bushway \& Sweeten, 2007; Mythen, 2014). Finally, and not least importantly, the "regulatory approach" does not extend to CCs ex post facto guarantees prohibiting the enactment of retroactive burdensome restrictions hindering ex-offenders' reentry.

\section{Collateral Consequences as Part of the Sentencing Context}

In recent years, the American Bar Association (2004), the Uniform Law Commission (2010), and the American Law Institute (2017) have put forward broad recommendations aimed at integrating, to various degrees, CCs into the sentencing process, but not as formal criminal penalties. Such proposals do not make CCs part of the sentence but rather part of the sentencing context.

All three recommendations present common features: (1) identify, collect, and publish CCs so that judges, defendants, prosecutors, and policy-makers can be aware of the full scope of civil penalties, disqualifications, and disabilities that follow a conviction; (2) incorporate CCs into the criminal process, particularly with regard to plea bargaining. This would allow to overcome the 
traditional direct/collateral dichotomy in the Supreme Court's jurisprudence for which a trial court must inform a defendant of the direct consequences of pleading guilty but not of the collateral restrictions and civil disabilities flowing from it; $^{13}$ (3) limit the number of applicable collateral sanctions to those justifiable for public safety reasons and for which the current offense provides a substantial basis for imposition; (4) provide relief mechanisms to eliminate or mitigate the impact of collateral sanctions to help the reentry process of ex-offenders.

Section 6 of the Uniform Law Commission's CCs of Conviction Act (thus far only adopted by the state of Vermont) provides for notice of CCs at sentencing and, in addition, if an individual is sentenced to imprisonment, at the time of release.

The statutory text of Model Penal Code: Sentencing, recently approved by the American Law Institute, re-examines the sentencing provisions of the ALI's 1962 Model Penal Code. It provides that, at the time of sentencing, the court shall inform the offender of "all CCs that apply under state and federal law as a result of the current conviction." Judges shall also warn offenders that applicable CCs can change over time (i.e., the Ex Post Facto Clause does not apply) and in different jurisdictions, and that relief mechanism is available (\$ 7.04(1)). The MPC proposal also recommends giving courts the power to remove mandatory collateral restrictions related to employment, education, housing, public benefits, registration, and occupational licensing as early as sentencing and to certify rehabilitation after a period of law-abiding conduct. However, a courtissued order of relief would merely remove the mandatory nature of certain CCs. The final word on their imposition is left to the discretion of authorized decision-makers (e.g., licensing boards) on a case-by-case basis (Love, 2015, p. 280). In particular, the decision on whether to confer a discretionary opportunity or benefit "may be denied notwithstanding the court's order of relief if the conduct underlying the conviction is determined to be substantially related to the benefit or opportunity the individual seeks to obtain" (§ 7.04(3)).

Finally, the ABA Criminal Justice Standards go further, providing that "The legislature should authorize the sentencing court to take into account, and the court should consider, applicable collateral sanctions in determining an offender's overall sentence" (Standard 19-2.4(a); see also Love \& Chin, 2004). CCs and civil disabilities that adversely impact ex-offenders following a conviction would, therefore, be considered as a sentencing factor. However, as a "mere" sentencing factor, CCs could potentially be given little consideration in the exercise of the courts' sentencing discretion or balanced against other factors.

\section{Collateral Consequences as Formal Punishment}

The two policy frameworks discussed above acknowledge the jarring discrepancy between form and substance: CCs function and are experienced as punishment. Yet, at the same time, such proposals seem to be aimed mainly at curtailing the negative effects triggered by collateral restrictions rather than putting forward an alternative normative framework to deal more effectively with the pervasive problem represented by "collateral" sanctions. Many consequences 
formally labeled as nonpunitive "are anything but 'collateral' to a defendant" and "may, in fact, dwarf the criminal sanction" (Roberts, 2008, p. 740). Collateral sanctions almost invariably serve the function of constitutional punishment and the criminal justice system should account for it (Chin, 2012, p. 1830).

My suggestion is to reboot the discourse about civil disabilities and other "collateral" restrictions stemming from criminal convictions starting with the acknowledgment that "[t]he current collateral-consequences rule rests on doctrinally flawed ground, is outdated, and is simply bad theory and policy" (Roberts, 2008, p. 740). Afflictive and burdensome CCs should be fully integrated into the criminal process as additional criminal penalties. This means that they should be "converted into elements of a sentence" and become an integral part of sentencing law and policy (Demleitner, 2005, p. 359).

If promoted to the status of formal punishment, collateral restrictions would enjoy the full panoply of constitutional guarantees that apply to criminal statutes, in particular, the prohibitions on ex post facto laws and double jeopardy. In this scenario, the sentencing judge would be the only decision-maker in charge for imposing those penalties. Under the proposed framework, no room would be left for collateral legal sanctions imposed automatically on a person upon conviction that are totally disconnected from the criminal justice process. As formal criminal punishments, "collateral" sanctions would be systematized and largely reduced in number. Legal disabilities would be imposed only when deemed appropriate in connection with the offense being sentenced, in any case for a limited period of time.

Disabilities, restrictions, and disqualifications provided for in criminal statutes should be germane to the characteristics of the offense of conviction, so that the punishment truly fit the crime. Triggering offenses should be indicated by reference to specific statutes and/or categories (e.g., offenses involving physical violence) instead of broad categories or vague definitions (e.g., crimes involving "moral turpitude"). For example, disenfrachisement should not be linked to any felony other than those connected with the exercise of the franchise; professional disqualifications should be available only for offenses in relation to which they can actually serve the purpose of minimizing the offender's specific risk of reoffending (e.g., disqualification from childcare professions in case of a conviction for sexual assault of a minor, or disqualification from the exercise of managerial or executive functions bearing a direct relationship to the conduct constituting the offense in case of a conviction for a crime involving fraud or deceit).

Furthermore, and very importantly, as an integral part of the overall sentence, the imposition of such disabilities as criminal punishment should be constrained by a retributive as well as utilitarian notion of proportionality. As a result, fewer restrictions would be imposed and for shorter periods of time; a halt would be put to the current, substantially unchecked, "piling on" of the $\mathrm{CCs}$ of a criminal conviction. Reimagining CCs as criminal penalties would enable sentencing courts to better calibrate the sentence. Nowadays, too many prison sentences are imposed. Broadening the number of applicable punishments would ultimately help the penal system move beyond the overly polarized and 
prison-centric arsenal of criminal sanctions currently available (Morris \& Tonry, 1990). It is well known that the Supreme Court's jurisprudence seems "to recognize meaningful proportionality constraints in all punishment contexts other than that of prison duration" (Frase, 2005, p. 599). The innovation I propose here would contribute to a gradual shift toward more eclectic sentencing policies and practices, with shorter prison terms being imposed and portions of them being "replaced" by temporary disabilities or disqualifications, if available and deemed appropriate. Following release from prison or discharge from probation or parole, restrictions imposed as part of the sentence should be removable by means of court-issued orders granted at the request of the person concerned after the passage of a predetermined crime-free period and upon presentation of evidence of effective active redemption.

With regard to collateral sanctions discretionarily imposed by decisionmakers located outside the criminal justice system following a background check (especially stigmatization and employment and housing discrimination), access to and dissemination of criminal history information should be restricted and heavily regulated in order to prevent shunning and internal exile. Today, a strong public policy preference exists in the United States for the openness of criminal records. First Amendment considerations, open government principles, and the need for public control over the administration of criminal justice are routinely invoked to justify this approach. Criminal records are available to the general public through a vast array of sources, such as court records databases, federal and state criminal history repositories, and private vendors' websites (Jacobs, 2015). At the same time, however, Europe shows that an open criminal records policy is not an inevitable feature of democratic and transparent government in the Digital Age. Policy-making with regard to the availability and dissemination of criminal records should properly take into account competing individual and societal interests that are equally valid and compelling, in particular, the rehabilitation of ex-offenders (Corda, 2016, 2018).

Lastly, it must be noted that the idea of delegating the task of protecting society from dangerous individuals to private players such as employers and landlords through criminal background investigation appears to rely on the controversial assumption that, compared to the state, "they are in a better position to provide safety, albeit at the cost of eventually engaging in discriminatory practices" (Larrauri, 2014, p. 62). In contrast to this approach, I believe that the criminal law and criminal justice actors are better equipped to do so. Additional penalties imposed at sentencing in the form of occupational disqualifications or other temporary restrictions would represent an effective tool to minimize risks that may extend beyond the completion of a term of imprisonment or community supervision.

\section{CONCLUSION}

Collateral consequences of convictions substantially hinder the reintegration of ex-offenders long after the sentence has been served in full and increase the likelihood of recidivism. A vast number of them operate regardless of whether an 
offender has been convicted for a felony or a misdemeanor and irrespective of whether he or she has been sentenced to incarceration, probation, or the payment of a fine. Although CCs formally operate beyond and independently of the sentence imposed in a criminal court, this chapter has shown that they represent an integral component of the contemporary penal landscape in the United States.

Today, US criminal justice policies are slowly starting to sober up after the punitive hangover that lasted from the mid-1980s to (at least) the mid-2000s. While we are witnessing "legislative and political signs of penal-climate change" (Green, 2015, p. 273), a clear and consistent pattern is yet to be detected (Beckett, Reosti, \& Knaphus, 2016; Tonry, 2016). For a long time, CCs have been left out of the picture of the overall punitive response triggered by a criminal conviction. Ongoing discussions on sentencing reform cannot forget about them: the paradox would be apparent. Even if sentencing policies and practices moved toward more lenient outcomes (at least for some categories of offenses), the system would maintain its exclusionary harshness nearly intact in the postsentence life of ex-offenders.

An inherent contradiction exists, for example, in policies of massive investments in reentry programs (e.g., the Second Chance Act Grant Program) that simultaneously leave collateral restrictions out of the equation. Attempts to legislate reintegration or "smart reentry" are doomed to fail if the issue of CCs is not considered and tackled properly and effectively. Likewise, no reform aimed at moving away from mass incarceration and overreliance on penal control can ultimately succeed if indirect ramifications of "being a criminal" are ignored. Collateral restrictions flowing from a criminal conviction should no longer represent "invisible ingredients in the legislative menu of criminal sanctions" (Travis, 2002, p. 17). As I have argued in this chapter, CCs should be fully integrated into the sentencing process as a formal part of the sentence, thus moving beyond the legal fiction of the divide between direct and indirect consequences of a criminal conviction. The future of American criminal justice is still unwritten, but unquestionably CCs will represent a critical litmus test for sentencing reform in the years to come.

\section{NOTES}

1. The German Penal Code, respectively in sections 44 and 45 , further distinguishes between Nebenstrafen (additional criminal penalties) and Nebenfolgen (collateral consequences of conviction). The only listed additional criminal penalty is temporary driving ban. Collateral consequences include various bans and disqualification that are usually labeled as ancillary penalties in other continental jurisdictions. Some scholars hold the view that Nebenfolgen are not criminal penalties in a narrow sense as they are not so labeled. On the contrary, other scholars consider the fact that both sections 44 and 45 are listed under the heading of Title I on "Criminal penalties" (Strafen) - forming part of Chapter 3 of the Penal Code devoted to "Legal Sanctions" broadly defined (Rechtsfolgen) - as a decisive argument for their penal nature. Chapter 3 also includes a Title VI listing a range of "Measures of rehabilitation and incapacitation" (Maßregeln der Besserung und Sicherung) having purely preventive goals. Among those provisions, sections 69 and 70 provide for, respectively, disqualification from driving and disqualification 
from exercising a profession. Strictly speaking, these are not criminal penalties since their imposition does not presuppose that the offender acted in a blameworthy fashion (i.e., no proof of guilt is required).

2. For example, Article 65 of the Portuguese Penal Code is very clear in stating that a criminal conviction does not necessarily result in the loss of civil, professional, or political rights. Rather, the law may link the commission of specified offenses to losing certain rights and privileges or to the ban on exercising certain professions.

3. Available data suggest that nearly $90 \%$ of employers conduct background checks on job applicants at some point of the hiring process (Society for Human Resource Management, 2012).

4. As of 2016, 18 states have completely abandoned the federal ban on drug offenders receiving food stamps. Twenty-six other states have partly eased those restrictions. Only six states (Alaska, Georgia, Mississippi, South Carolina, West Virginia, and Wyoming) continue to fully enforce the War on Drugs-era ban. As for welfare benefits for drug felons, 13 states continue to prohibit anyone with a drug-related conviction from getting welfare benefits, and 23 others maintain a partial ban (Hager, 2016).

5. In the United States, more than one million felony convictions are pronounced every year in state and federal courts. Only half, approximately, result in a prison term (Rosenmerkel, Durose, \& Farole, 2009). Over 10 million misdemeanor cases are prosecuted in the same time.

6. The seven-factors are: (1) whether the sanction involves an affirmative disability or restraint, (2) whether it has historically been regarded as a punishment, (3) whether it comes into play only on a finding of scienter, (4) whether its operation will promote the traditional aims of punishment - retribution and deterrence, (5) whether the behavior to which it applies is already a crime, (6) whether an alternative purpose to which it may rationally be connected is assignable for it, and (7) whether it appears excessive in relation to the alternative purpose assigned.

7. The state of Michigan appealed the Sixth Circuit decision before the Supreme Court. In October 2017, the Court denied review, and in so doing upheld the ruling. Hence, Michigan has been prevented from extending new sex offender registry rules retroactively to registrants who had been convicted before the new provisions were enacted.

8. See, for example, Article 49(3) of the Charter of Fundamental Rights of the European Union: "The severity of penalties must not be disproportionate to the criminal offense."

9. As a matter of fact, US courts conduct little proportionality analysis on any punishment outside the death penalty context (Steiker \& Steiker, 2016, pp. 276-282).

10. Evidence of this is provided by the fact that several European countries embrace rehabilitation as a constitutional mandate. See, for example, Article 27(3) of the Italian Constitution of 1948: "Punishment cannot consist in treatments contrary to human dignity and must aim at rehabilitating the convicted offender"); and Article 25(2) of the Spanish Constitution of 1978: "Punishments entailing imprisonment and security measures shall be aimed at re-education and social rehabilitation and may not involve forced labor." The German Federal Constitutional Court in the famous life imprisonment case of 1977 (BVerfGE 45, 187, June 21, 1977) maintained that rehabilitation is "constitutionally required in any community that establishes human dignity as its center piece and commits itself to the principle of social justice."

11. It must be acknowledged that supra-national courts traditionally have more leeway in looking beyond legislative classifications of domestic law compared to national courts.

12. The two proceedings were conducted in parallel and the facts established in one proceeding were used in the other one. Furthermore, the sentence imposed following conviction at trial had regard to the penalty imposed in the administrative proceeding.

13. A notable exception to the direct/collateral dichotomy has been established for deportation by the Supreme Court in the case of Padilla vs Kentucky (2010). 


\section{ACKNOWLEDGMENTS}

This chapter greatly benefited from thought-provoking conversations with Michael Tonry and Dirk van Zyl Smit. I am also sincerely appreciative of the comments of an anonymous reviewer, whose feedback proved extremely helpful in improving and refining the manuscript. This chapter is part of a larger project on the role and impact of collateral consequences of criminal convictions in contemporary penal policy.

\section{REFERENCES}

A and B vs Norway, ECHR [GC], Apps. Nos. 24130/11 and 29758/11 (2016).

Alexander, M. (2010). The new Jim Crow. Mass incarceration in the age of colorblindness. New York, NY: The New Press.

Allen, F. A. (1981). The decline of the rehabilitative ideal: Penal policy and social purpose. New Haven, CT: Yale University Press.

American Bar Association. (2004). ABA standards for criminal justice: Collateral sanctions and discretionary disqualification of convicted persons (3rd ed.). Washington, DC: American Bar Association.

American Law Institute (2017). Model penal code: Sentencing (official statutory text, adopted May 24, 2017). Philadelphia, PA: The American Law Institute.

Ashworth, A. (2008). Conceptions of overcriminalization. Ohio State Journal of Criminal Law, 5, $407-425$.

Ashworth, A. (2015). Sentencing and criminal justice (6th ed.). Cambridge: Cambridge University Press.

Ashworth, A., \& Horder, J. (2013). Principles of criminal law (7th ed.). Oxford: Oxford University Press.

Beckett, K., \& Murakawa, N. (2012). Mapping the shadow carceral state: Toward an institutionally Capacious approach to punishment. Theoretical Criminology, 16(2), 221-244.

Beckett, K., Reosti, A., \& Knaphus, E. (2016). The end of an era? Understanding the contradictions of criminal justice reform. Annals of the American Academy of Political and Social Science, $664,238-259$.

Blackstone, W. (1769). Commentaries on the laws of England (Vol. 4). Oxford: Oxford University Press.

Blumstein, A., \& Nakamura, K. (2009). Redemption in the presence of widespread criminal background checks. Criminology, 47(2), 327-359.

Bushway, S., \& Sweeten, G. (2007). Abolish lifetime bans for ex-felons. Criminology \& Public Policy, 6(4), 697-706.

BVerfGE 45, 187 (21 June 1977, 1 BvL 14/76).

Carson, E. A. (2014). Prisoners in 2013. Washington, DC: U.S. Department of Justice, Bureau of Justice Statistics.

Carson, E. A., \& Anderson, E. (2016). Prisoners in 2015. Washington, DC: U.S. Department of Justice, Bureau of Justice Statistics.

Carson, E. A., \& Golinelli, D. (2013). Prisoners in 2012: Trends in admissions and releases, 1991-2012. Washington, DC: U.S. Department of Justice, Bureau of Justice Statistics.

Chin, G. J. (2012). The new civil death: Rethinking punishment in the era of mass conviction. University of Pennsylvania Law Review, 160, 1789-1833.

Cohen, N. P., \& Rivkin, D. H. (1971). Civil disabilities: The forgotten punishment. Federal Probation, 35(1), 19-25.

Corda, A. (2016). More justice and less harm: Reinventing access to criminal history records. Howard Law Journal, 60, 1-60.

Corda, A. (2018). Beyond Totem and Taboo: Toward a narrowing of American criminal record exceptionalism. Federal Sentencing Reporter, 30(4/5), 241-251.

Cullen, F. T., Lero Jonson, C., \& Mears, D. P. (2017). Reinventing community corrections. Crime \& Justice, 47, 27-93.

Damaška, M. R. (1968). Adverse legal consequences of conviction and their removal: A comparative study. Journal of Criminal Law, Criminology \& Police Science, 59, 347-360. 
Demleitner, N. V. (2000). Continuing payment of one's debt to society: The German model of felon disenfranchisement as an alternative. Minnesota Law Review, 84, 753-804.

Demleitner, N. V. (2005). Smart public policy: Replacing imprisonment with targeted nonprison sentences and collateral sanctions. Stanford Law Review, 58, 339-360.

Demleitner, N. V. (2009). U.S. Felon Disenfranchisement: Parting ways with Western Europe. In A. Ewald \& B. Rottinghaus (Eds.), Criminal disenfranchisement in an international perspective. New York, NY: Cambridge University Press.

Demleitner, N. V. (2014). Types of punishment. In M. D. Dubber \& T. Hörnle (Eds.), The Oxford handbook of criminal law. New York, NY: Oxford University Press.

Demleitner, N. V. (2016). Judicial challenges to the collateral impact of criminal convictions: Is true change in the offing? New York University Law Review Online, 91, 150-170.

Dershowitz, A. M. (1973). Preventive confinement: A suggested framework for constitutional analysis. Texas Law Review, 51, 1277-1324.

Doe vs Dept. of Pub. Safety \& Corr. Servs., 430 Md. 535, 62 A.3d 123 (2013).

Does \#1-5 vs Snyder, 834 F.3d 696 (6th Cir. 2016).

Engel and Others vs the Netherlands, ECHR, Apps. Nos. 5100/71, 5101/71, 5102/71, 5354/72, 5370/ $72(1976)$.

Ewald, A. C. (2002). "Civil death": The ideological paradox of criminal disenfranchisement law in the United States. Wisconsin Law Review, 2002, 1045-1132.

Ewald, A. C. (2011). Collateral consequences and the perils of categorical ambiguity. In A. Sarat, L. Douglas, \& M. Merrill Umphrey (Eds.), Law as punishment/law as regulation. Palo Alto, CA: Stanford University Press.

Ewing vs California, 538 U.S. 11 (2003).

Feeley, M., \& Simon, J. (1992). The new penology: Notes on the emerging strategy of corrections and its implications. Criminology, 30(4), 449-474.

Feeley, M., \& Simon, J. (1994). Actuarial justice: The emerging criminal law. In D. Nelken (Ed.), The futures of criminology. London: Sage.

Frase, R. S. (2005). Excessive prison sentences, punishment goals, and the eighth amendment: "Proportionality" relative to what? Minnesota Law Review, 89, 571-651.

Frase, R. S. (2013). Just sentencing: Principles and procedures for a workable system. New York, NY: Oxford University Press.

Gardel vs France. (2009). ECHR, App. No. 16428/05.

Garland, D. (2001a). Introduction: The meaning of mass imprisonment. In D. Garland (Ed.), Mass imprisonment: Social causes and consequences. London: Sage.

Garland, D. (2001b). The culture of control: Crime and social order in contemporary society. Chicago, IL: Chicago University Press.

Garland, D. (2016). The welfare state: A very short introduction. New York, NY: Oxford University Press.

Garland, D. (2017). Penal power in America: Forms, functions and foundations. Journal of the British Academy, 5, 1-35.

Glaeser, E. L., \& Shleifer, A. (2003). The rise of the regulatory state. Journal of Economic Literature, 41(2), 401-425.

Green, D. A. (2015). U.S. penal-reform catalysts, drivers, and prospects. Punishment \& Society, 17(3), $271-298$.

Hager, E. (2016). Six states where felons can't get food stamps. Marshall Project, February 4. Retrieved from https:/www.themarshallproject.org/2016/02/04/six-states-where-felons-can-tget-food-stamps\#.GvSkfQWhi

Hamilton, M. (2015). Risk-needs assessment: Constitutional and ethical challenges. American Criminal Law Review, 52, 231-291.

Hoppe, T. (2016). Punishing sex: Sex offenders and the missing punitive turn in sexuality studies. Law \& Social Inquiry, 41(3), 573-594.

Hoskins, Z. (2016). Collateral restrictions. In C. Flanders \& Z. Hoskins (Eds.), The new philosophy of criminal law. London: Rowman \& Littlefield International.

Husak, D. (2016). Does the state have a monopoly to punish crime? In C. Flanders \& Z. Hoskins (Eds.), The new philosophy of criminal law. London: Rowman \& Littlefield International. 
Itzkowitz, H., \& Oldak, L. (1973). Restoring the ex-offender's right to vote: Background and developments. American Criminal Law Review, 11, 721-770.

Jackson, L. F., \& Feige, D. (2013). Sex offender village. New York Times. May 21. Retrieved from http://www.nytimes.com/2013/05/22/opinion/sex-offender-village.html?_r=2\&.

Jacobs, J. B. (2015). The eternal criminal record. Cambridge, MA: Harvard University Press.

Jones, T., \& Newburn, T. (2013). Policy convergence, politics and comparative penal reform: Sex offender notification schemes in the USA and UK. Punishment \& Society, 15(5), 439-467.

Kafkaris vs Cyprus, ECHR [GC], App. No. 21906/04 (2008).

Kaiser, J. (2016a). Revealing the hidden sentence: How to add legitimacy, purpose, and transparency to "collateral" punishment policy. Harvard Law \& Policy Review, 10, 123-184.

Kaiser, J. (2016b). We know it when we see it: The tenuous line between "direct punishment" and "collateral consequences". Howard Law Journal, 59, 341-372.

Kansas vs Hendricks, 521 U.S. 346 (1997).

Kennedy vs Mendoza-Martinez, 372 U.S. 144 (1963).

Kleinfeld, J. (2016). Two cultures of punishment. Stanford Law Review, 68, 933-1036.

Kurlychek, M. C., Brame, R., \& Bushway, S. (2007). Enduring risk? Old criminal records and predictions of future criminal involvement. Crime \& Delinquency, 53(1), 64-83.

Lageson, S. E. (2017). Crime data, the internet, and free speech: An evolving legal consciousness. Law \& Society Review, 51(1), 8-41.

Larrauri, E. (2014). Legal protections against criminal background checks in Europe. Punishment \& Society, 16(1), 50-73.

Law, M. T., \& Kim, S. (2011). The rise of the American regulatory state: A view from the progressive era. In D. Levi-Faur (Ed.), Handbook on the politics of regulation. Cheltenham: Edward Elgar.

Levin, B. (2018). Criminal employment law. Cardozo Law Review, 39 (forthcoming). Retrieved from https://papers.ssrn.com/sol3/papers.cfm?abstract_id $=2944840$

Logan, W. A. (1998). The Ex Post Facto clause and the jurisprudence of punishment. American Criminal Law Review, 35, 1261-1318.

Logan, W. A. (2009). Criminal registration and community notification laws in America. Palo Alto, CA: Stanford University Press.

Logan, W. A. (2013). Informal collateral consequences. Washington Law Review, 88, 1103-1117.

Love, M. C. (2015). Managing collateral consequences in the sentencing process: The revised sentencing articles of the model penal. Wisconsin Law Review, 2015, 247-287.

Love, M. C., \& Chin, G. J. (2004). Old wine in a new skin: The ABA standards on collateral sanctions and discretionary disqualification of convicted persons. Federal Sentencing Reporter, 16(3), 232-240.

Love, M. C., Roberts, J. M., \& Klingele, C. (2016). Collateral consequences of criminal convictions: Law, policy and practice (2nd ed.). St. Paul, MN: Thomson Reuters.

Lucken, K. (2013). You say regulation, I say punishment: The semantics and attributes of punitive activity. Critical Criminology, 21(2), 193-210.

M. vs Germany, ECHR, Appl. No. 19359/04 (2009).

Manza, J., \& Uggen, C. (2006). Locked out: Felon disenfranchisement and American democracy. New York, NY: Oxford University Press.

Maruna, S. (2001). Making good: How ex-offenders reform and reclaim their lives. Washington, DC.: American Psychological Association Books.

Mauer, M. (2001). The causes and consequences of prison growth in the United States. In D. Garland (Ed.), Mass imprisonment: Social causes and consequences. London: Sage.

Mayson, S. G. (2015). Collateral consequences and the preventive state. Notre Dame Law Review, 91, $301-361$.

McLennan, R. (2011). The convict's two lives: Civil and natural death in the American prison. In D. Garland, R. McGowen, \& M. Meranze (Eds.), America's death penalty: Between past and present. New York, NY: New York University Press.

McNeill, F. (2016). What good is punishment? In S. Farrall, B. Goldson, I. Loader, \& A. Dockle (Eds.), Justice and penal reform: Re-shaping the penal landscape. New York, NY: Routledge.

Mears, D. P., \& Cochran, J. C. (2015). Prisoner reentry in the era of mass incarceration. Thousand Oaks, CA: Sage. 
Morris, N., \& Tonry, M. (1990). Between prison and probation: Intermediate punishments in a rational sentencing system. New York, NY: Oxford University Press.

Mythen, G. (2014). Understanding the risk society crime, security and justice. Basingstoke: Palgrave Macmillan.

Olivares, K. M., Burton, V. S., \& Cullen, F. T. (1996). The collateral consequences of a felony conviction: A national study of state legal codes 10 years later. Federal Probation, 60(3), 10-17.

Padilla vs Kentucky, 559 U.S. 356 (2010).

Parkes, D. L. (2003). Ballot boxes behind bars: Toward the repeal of prisoner disenfranchisement laws. Temple Political \& Civil Rights Law Review, 13, 71-111.

Petersilia, J. (2003). When prisoners come home: Parole and prisoner reentry. New York, NY: Oxford University Press.

Pettus, K. I. (2013). Felony disenfranchisement in America: Historical origins, institutional racism, and modern consequences (2nd ed.). Albany, NY: State University of New York Press.

Pfaff, J. (2017). Locked in: The true causes of mass incarceration and how to achieve real reform. New York, NY: Basic Books.

Phelps, M. S. (2013). The paradox of probation: Community supervision in the age of mass incarceration. Law \& Policy, 35(1-2), 51-80.

Pinard, M. (2006). An integrated perspective on the collateral consequences of criminal convictions and reentry issues faced by formerly incarcerated individuals. Boston University Law Review, $86,623-690$.

Pinard, M. (2010). Collateral consequences of criminal convictions: Confronting issues of race and dignity. New York University Law Review, 85, 457-534.

Reitz, K. R. (Ed.). (2018). American exceptionalism in crime and punishment. New York, NY: Oxford University Press.

Rice Leave, T. (2009). Only yesterday: The rise and fall of twentieth century sexual psychopath laws. Louisiana Law Review, 69, 549-591.

Roberts, J. M. (2008). The mythical divide between collateral and direct consequences of criminal convictions: Involuntary commitment of "sexually violent predators". Minnesota Law Review, 93, 670-740.

Roberts, J. M. (2011). Why misdemeanors matter: Defining effective advocacy in the lower criminal courts. University of California, Davis Law Review, 45, 277-372.

Robinson, P. H. (2005). Fair notice and fair adjudication: Two kinds of legality. University of Pennsylvania Law Review, 154, 335-398.

Rosenmerkel, S., Durose, M., \& Farole, D. (2009). Felony sentences in state courts, 2006: Statistical tables. Washington, DC: U.S. Department of Justice, Bureau of Justice Statistics.

Saunders, H. R. (1970). Civil death: A new look at an ancient doctrine. William \& Mary Law Review, $11,988-1003$.

Schabas, W. A. (2015). The European convention on human rights: A commentary. Oxford: Oxford University Press.

Schofield, H. (1911). Cruel and unusual punishment. Illinois Law Review, 5, 321-335.

Silva, L. R. (2015). Collateral damage: A public housing consequence of the "war on drugs". University of California Irvine Law Review, 5, 783-811.

Simon, J. (1993). Poor discipline: Parole and the social control of the underclass 1890-1990. Chicago, IL: University of Chicago Press.

Simon, J. (2007). Governing through crime. How the war on crime transformed American democracy and created a culture of fear. New York, NY: Oxford University Press.

Singer, R. G. (2002). Conviction: Civil disabilities. In J. Dressler (Ed.), Encyclopedia of crime \& justice (2nd ed., Vol. 1). St. Paul, MN: Thomson Reuters.

Slobogin, C. (2013). Preventive detention in the United States and Europe. In M. Caianello \& M. L. Corrado (Eds.), Preventing danger: New paradigms in criminal justice. Durham, NC: Carolina Academic Press.

Smith vs Doe, 538 U.S. 84 (2003).

Society for Human Resource Management (2012). Background checking:The use of criminal background checks in hiring decisions. Retrieved from https://www.shrm.org/hr-today/trends-andforecasting/research-and-surveys/Pages/criminalbackgroundcheck.aspx. 
Sohm, R. (1892). In J.C. Ledlie (Trans.), The Institutes of Roman Law. Oxford: Clarendon Press.

Sohoni, T. W. P. (2013). The effect of collateral consequence laws on state rates of returns to prison. Ph.D. dissertation, University of Maryland, College Park. Retrieved from http://drum.lib. umd.edu/handle/1903/14915.

Special Project (1970). The collateral consequences of a criminal conviction. Vanderbilt Law Review, $23,929-1241$.

Steiker, C. S., \& Steiker, J. M. (2016). Courting death: The Supreme Court and capital punishment. Cambridge, MA: Harvard University Press.

Tewksbury, R. (2007). Exile at home: The unintended collateral consequences of sex offender residency restrictions. Harvard Civil Rights-Civil Liberties Law Review, 42, 531-540.

Tonry, M. (1996). Sentencing matters. New York, NY: Oxford University Press.

Tonry, M. (2016). Sentencing fragments: Penal reform in America, 1975-2025. New York, NY: Oxford University Press.

Travis, J. (2002). Invisible punishment: An instrument of social exclusion. In M. Mauer \& M. Chesney-Lind (Eds.), Invisible punishment: The collateral consequences of mass imprisonment. New York, NY: The New Press.

Travis, J. (2005). But they all come back: Facing the challenges of prisoner reentry. Washington, DC.: Urban Institute Press.

Tripkovic, M. (2016). The modern Cives Sine Suffragio: Dimensions of criminal disenfranchisement in Europe. Howard Journal of Crime and Justice, 55(1-2), 4-24.

Trop vs Dulles, 356 U.S. 86 (1958).

Uggen, C., Behrens, A., \& Manza, J. (2005). Criminal disenfranchisement. Annual Review of Law and Social Science, 1, 307-322.

Uggen, C., Larson, R., \& Shannon, S. (2016). 6 million lost voters: State-level estimates of felony disenfranchisement. Washington, DC.: The Sentencing Project.

Uggen, C., \& Stewart, R. (2015). Piling on: Collateral consequences and community supervision. Minnesota Law Review, 99, 1871-1912.

Uniform Law Commission (2010). Uniform collateral consequences of conviction act. Retrieved from http://www.uniformlaws.org/shared/docs/collateral_consequences/uccca_final_10.pdf.

van Zyl Smit, D., \& Corda, A. (2018). American exceptionalism in Parole release and supervision: A European perspective. In K. R. Reitz (Ed.), American exceptionalism in crime and punishment. New York, NY: Oxford University Press.

von Bar, C. L. (1916). A history of continental criminal law. Boston, MA: Little, Brown, and Company.

von Hirsch, A., \& Wasik, M. (1997). Civil disqualifications attending conviction: A suggested conceptual framework. Cambridge Law Journal, 56(3), 599-626.

von Savigny, F. C. (1884). In W.H. Rattigan (Trans.), System of modern Roman Law (Vol. 2). Jural relations: Or, the Roman Law of persons as subjects of jural relations. London: Wildy \& Sons.

Welch vs the United Kingdom, ECHR, App. No. 17440/ 90 (1995).

Whitman, J. Q. (2003). Harsh justice: Criminal punishment and the widening divide between America and Europe. New York, NY: Oxford University Press.

Whittle, T. N. (2018). Felony collateral sanctions effects on recidivism: A literature review. Criminal Justice Policy Review, 29(5), 505-524

Wolff, M. A. (2011). Incorporating collateral consequences into sentencing guidelines and recommendations Post-Padilla. Saint Louis University Public Law Review, 31, 183-192.

Zedner, L. (2016). Penal subversions: When is a punishment not punishment, who decides and on what grounds? Theoretical Criminology, 20(1), 3-20.

Zimring, F. E. (2010). The scale of imprisonment in the United States: Twentieth century patterns and twenty-first century prospects. Journal of Criminal Law \& Criminology, 100, 1225-1245.

Zimring, F. E., \& Hawkins, G. J. (1991). The scale of imprisonment. Chicago, IL: Chicago University Press. 